\title{
The Pathogenesis of Eosinophilic Esophagitis: Beyond the Eosinophil
}

\author{
Evan S. Dellon
}

Received: 21 March 2013/Accepted: 27 March 2013/Published online: 27 April 2013

(C) Springer Science+Business Media New York 2013

\section{Introduction}

Over the past two decades, eosinophilic esophagitis (EoE) has undergone a remarkable transformation. What used to be a rare, case-reportable condition about which little was known, is now widely recognized as an important cause of upper GI morbidity and the subject of intense research activity. The clinical syndrome has been defined, treatment trials have been performed, and guidelines for diagnosis and management have been published [1]. In parallel with this has been a rapid increase in our understanding of the pathogenesis and genetic basis of EoE [2-5]. While the consensus is that EoE is an allergic/immune-mediated condition in which the eosinophil plays a central role, recent data suggest that "non-eosinophil cell types" play important, and possibly crucial, roles as well. The allergic basis for the disease is based on several lines of evidence. Patients with EoE have a high burden of concomitant atopic conditions [6-10], allergen-free elemental diets cause nearly universal improvement in symptoms and resolution of eosinophilia $[11,12]$, and there is a seasonal variation in EoE, possibly due to aeroallergens [10, 13-16]. Prompted by the review by Zhang and colleagues in this issue of Digestive Diseases and Sciences [17], this editorial

E. S. Dellon $(\square)$

Center for Esophageal Diseases and Swallowing,

Center for Gastrointestinal Biology and Disease, Division

of Gastroenterology and Hepatology, Department of Medicine,

University of North Carolina School of Medicine, CB\#7080,

Bioinformatics Building, 130 Mason Farm Rd., Chapel Hill,

NC 27599-7080, USA

e-mail: edellon@med.unc.edu summarizes the role of the eosinophil and several other cell types in the pathogenesis of EoE, including lymphocytes, mast cells, fibroblasts, and epithelial cells. Recognizing and characterizing the role of the non-eosinophil cell types is likely to be central to future advances in the diagnosis and treatment of EoE.

\section{Eosinophils}

The importance of the eosinophil in EoE is almost a tautology-after all, it is classified as an allergic disease and called eosinophilic esophagitis. Since the normal human esophagus is normally devoid of eosinophils, their presence in the epithelium is abnormal [18]. While not pathognomonic for EoE, esophageal eosinophils are currently a requirement for the diagnosis of EoE [1, 19]. The understanding of why they are there and what they are doing, however, remains incomplete. Eosinophils are multifunctional cells which when activated secrete a wide variety of inflammatory mediators, cytokines, chemokines, neuromediators, and cytotoxic granule proteins [20]. Eosinophil activation and degranulation may mediate the pathogenesis of EoE [21, 22]. In particular, eosinophils induce esophageal remodeling via a TGF- $\beta$ pathway resulting in subepithelial fibrosis, epithelial-mesenchymal transition, and smooth muscle dysfunction, and increase the rate of epithelial proliferation in the esophagus [23-28]. This provides a possible explanation for clinical features of EoE such as dysphagia, esophageal rings, strictures, and dysmotility. In animal models of EoE, neither IL-5 deficient nor eosinophil deficient mice develop the experimental phenotype of EoE [29, 30]. Nevertheless, there is more to EoE than just eosinophils. 


\section{Lymphocytes}

In this issue of Digestive Diseases and Sciences, Zhang and colleagues [17] describe EoE as a disease process driven by Th-2 lymphocytes. Expression of Th2-associated cytokines, such as IL-4, IL-5, and IL-13 are increased in EoE [31-34]. Further, the abundance of CD3+ and CD8+ T cells, and to a lesser extent CD4+ cells, is increased in EoE, with pathobiological implications [35]. Adaptive T cell immunity is critical for developing EoE in mouse models, as illustrated in experiments where mice deficient in $\mathrm{B}$ cells develop EoE, whereas mice deficient in B and $\mathrm{T}$ cells do not [36]. B cells can generate local production of $\operatorname{IgE}$ in EoE via a class-switching mechanism, although this response is not required for initiating the inflammatory cascade that leads to the disease [36, 37].

The current model of EoE pathogenesis holds that antigens, either food allergens or aeroallergens, are presented to the esophagus and stimulate a Th2 response. IL-13 and IL-5, produced by lymphocytes, stimulate the esophageal epithelium to produce eotaxin-3, a potent chemokine, which then recruits and activates eosinophils [38]. Eotaxin-3 is associated strongly with the pathogenesis of EoE since it is the most upregulated gene and bears a disease-associated single nucleotide polymorphism (SNP) [3]. IL-13 is also essential. This cytokine induces EoE in a mouse model, and in human esophageal cell cultures IL-13 induces an RNA transcript expression profile similar to that of humans with EoE [3, 4, 39]. Another important factor is thymic stromal lymphopoietin (TSLP). A genome-wide association study identified a SNP in the TSLP associated with EoE, and TSLP expression was increased in EoE patients [5]. TSLP is an IL-7-like cytokine involved in the initiation of allergic responses in atopic diseases, likely through a dendritic cell-mediated Th2 response [40]. Although $\mathrm{T}$ cell co-stimulatory molecules are likely important in EoE pathogenesis, this hypothesis has yet to be fully tested [17].

\section{Mast Cells}

Mast cells have been implicated in the pathogenesis of EoE. The number of mast cells is increased in EoE compared to gastroesophageal reflux disease or healthy controls $[31,33,41-45]$. In some cases the number of mast cells is actually higher than the number of eosinophils; indeed, quantifying levels of tryptase positive mast cells has diagnostic utility in EoE [44]. Moreover, mast cell-associated genes such as carboxypeptidase A3, tryptase, and the histamine receptor are specifically upregulated in EoE, and normalize after treatment with a topical corticosteroid $[3,45]$.
Although the mechanisms underlying local esophageal mastocytosis have yet to be fully elucidated, they in part are prompted by the Th2 response in EoE, possibly via IL-9 [2]. The importance of mast cells is such that one author even proposed renaming the disease mastocytic esophagitis [46]. Furthermore, mast cells may represent a future therapeutic target. To date, only a small number of patients with EoE have been treated with the mast cell stabilizer cromolyn. Though they did not respond favorably, lack of success may have been due to suboptimal dosing and issues related to formulation and route of administration rather than true lack of efficacy [47]. A recent pilot study of a novel antagonist to the chemoattractant receptor-homologous molecule (prostaglandin D2 receptor) expressed on Th2 cells reported a modest but significant decrease in tissue eosinophilia compared to placebo in steroid-refractory EoE patients, further implicating mast cells, a major source of prostaglandin D2, in EoE pathogenesis [48].

\section{Fibroblasts}

Fibroblasts are also important in EoE, leading to the collagen deposition and esophageal scarring responsible for many of the clinical manifestations of EoE [27]. This process appears to be mediated by TGF- $\beta$, which is produced by eosinophils and mast cells $[24,28]$. A recently recognized mechanism for fibroblast differentiation and activation is the epithelial-mesenchymal transition, whereby epithelial cells transform to and acquire mesenchymal-type features $[25,49]$. TFG- $\beta$ also induces periostin production by fibroblasts [50]. Periostin expression is highly upregulated in EoE, increasing eosinophil adherence to fibronectin in the extracellular matrix. Therefore, periostin can perpetuate the cycle of eosinophilic inflammation in the esophagus $[3,50]$.

\section{Epithelial Cells}

Esophageal epithelial cells are another non-eosinophil cell involved in the pathogenesis of EoE. Normally, the epithelial cells in the human esophagus are joined by a series of tight junctions, adherens junctions, and desmosomes, which contain key proteins including claudin- 1 and -4 , E-cadherin, and desmoglein [51]. Spongiosis or dilated intercellular spaces is present in EoE histologically, indicative of a leaky barrier due to breakdown of junctional proteins [18]. Defects in barrier function can facilitate penetration of luminal antigens into the tissue, serving as the initial trigger for EoE. In this respect, some barrier proteins are differentially expressed in EoE [3]. Additionally, expression of filaggrin, also known as the epidermal differentiation complex, is decreased in patients with EoE 
and in an IL-13 stimulated EoE simulating experimental system [52]. Once antigens penetrate the epithelial barrier, eosinophils and even esophageal epithelial cells can present antigen [53, 54]. Clearly, the esophageal epithelium is more than a passive barrier for protection against noxious acid/peptic stimuli. It is an immunologically active tissue involved in the multiple inflammatory pathways in EoE.

\section{Conclusions}

There have been rapid developments in our understanding of the pathogenesis of EoE over the past decade, with an increasing recognition that cell types beyond the eosinophil are likely critical to disease development. Several genetic predispositions to EoE, including SNPs in eotaxin-3 and TSLP, have been implicated. The current model holds that food or environmental allergens contact a possibly leaky esophageal epithelium, triggering a Th2-mediated cytokine response where IL-5 and IL-13 stimulate the esophageal epithelium to produce eotaxin-3. Eotaxin-3, in turn, recruits eosinophils to the esophageal epithelium where they are activated. IL-13 down-regulates epidermal differentiation complex genes, further impairing the esophageal epithelial barrier. Th2 lymphocytes additionally produce IL-9 which recruits mast cells into the esophagus. Eosinophils and mast cells produce TGF- $\beta$, which induces the epithelial-mesenchymal transition and esophageal remodeling. Since the eosinophil is still considered to be central to this process, the disease should not yet be termed "mastocytic esophagitis," "Th2-ocytic esophagitis," "fibroblastic esophagitis," or "barrier-openic esophagitis." Yet, the recognition of the importance of non-eosinophil cell types in EoE is an important step forward. The presence of these cells may help to define EoE clinical sub-phenotypes, explain persistent symptoms in some patients who have resolution of esophageal eosinophilia after treatment, and open areas where novel or combination therapies can be explored.

Acknowledgments This manuscript is funded, in part, by NIH K23DK090073. Evan S. Dellon received research funding from AstraZeneca, Mertiage Pharma, NIH, AGA, ACG, UNC, and the CURED Foundation.

\section{Conflict of interest None.}

\section{References}

1. Liacouras CA, Furuta GT, Hirano I, et al. Eosinophilic esophagitis: updated consensus recommendations for children and adults. J Allergy Clin Immunol. 2011;128:3-20.e6.

2. Abonia JP, Rothenberg ME. Eosinophilic esophagitis: rapidly advancing insights. Annu Rev Med. 2012;63:421-434.
3. Blanchard C, Wang N, Stringer KF, et al. Eotaxin-3 and a uniquely conserved gene-expression profile in eosinophilic esophagitis. J Clin Invest. 2006;116:536-547.

4. Blanchard C, Mingler MK, Vicario M, et al. IL-13 involvement in eosinophilic esophagitis: transcriptome analysis and reversibility with glucocorticoids. J Allergy Clin Immunol. 2007;120: 1292-1300.

5. Rothenberg ME, Spergel JM, Sherrill JD, et al. Common variants at $5 \mathrm{q} 22$ associate with pediatric eosinophilic esophagitis. Nat Genet. 2010;42:289-291.

6. Spergel JM, Brown-Whitehorn TF, Beausoleil JL, et al. 14 years of eosinophilic esophagitis: clinical features and prognosis. J Pediatr Gastroenterol Nutr. 2009;48:30-36.

7. Assa'ad AH, Putnam PE, Collins MH, et al. Pediatric patients with eosinophilic esophagitis: an 8-year follow-up. J Allergy Clin Immunol. 2007;119:731-738.

8. Roy-Ghanta S, Larosa DF, Katzka DA. Atopic characteristics of adult patients with eosinophilic esophagitis. Clin Gastroenterol Hepatol. 2008;6:531-535.

9. Penfield JD, Lang DM, Goldblum JR, Lopez R, Falk GW. The role of allergy evaluation in adults with eosinophilic esophagitis. J Clin Gastroenterol. 2010;44:22-27.

10. Dellon ES, Gibbs WB, Fritchie KJ, et al. Clinical, endoscopic, and histologic findings distinguish eosinophilic esophagitis from gastroesophageal reflux disease. Clin Gastroenterol Hepatol. 2009; 7:1305-1313.

11. Kelly KJ, Lazenby AJ, Rowe PC, et al. Eosinophilic esophagitis attributed to gastroesophageal reflux: improvement with an amino acid-based formula. Gastroenterology. 1995;109:1503-1512.

12. Markowitz JE, Spergel JM, Ruchelli E, Liacouras CA. Elemental diet is an effective treatment for eosinophilic esophagitis in children and adolescents. Am J Gastroenterol. 2003;98:777-782.

13. Prasad GA, Alexander JA, Schleck CD, et al. Epidemiology of eosinophilic esophagitis over three decades in Olmsted County, Minnesota. Clin Gastroenterol Hepatol. 2009;7:1055-1061.

14. Almansa C, Krishna M, Buchner AM, et al. Seasonal distribution in newly diagnosed cases of eosinophilic esophagitis in adults. Am J Gastroenterol. 2009;104:828-833.

15. Fogg MI, Ruchelli E, Spergel JM. Pollen and eosinophilic esophagitis. J Allergy Clin Immunol. 2003;112:796-797.

16. Moawad FJ, Veerappan GR, Lake JM, et al. Correlation between eosinophilic oesophagitis and aeroallergens. Aliment Pharmacol Ther. 2010;31:509-515.

17. Zhang Z, Sferra TJ, Eroflu Y. T cell co-stimulatory molecules: a co-conspirator in the pathogenesis of eosinophilic esophagitis? Dig Dis Sci. (Epub ahead of print). doi:10.1007/s10620-013-2599-8.

18. Collins MH. Histopathologic features of eosinophilic esophagitis. Gastrointest Endosc Clin N Am. 2008;18:59-71; viii-ix.

19. Dellon ES. Diagnosis and management of eosinophilic esophagitis. Clin Gastroenterol Hepatol. 2012;10:1066-1078.

20. Rothenberg ME, Hogan SP. The eosinophil. Аnпu Rev Immunol. 2006;24:147-174.

21. Justinich CJ, Ricci A Jr, Kalafus DA, et al. Activated eosinophils in esophagitis in children: a transmission electron microscopic study. J Pediatr Gastroenterol Nutr. 1997;25:194-198.

22. Mueller S, Aigner T, Neureiter D, Stolte M. Eosinophil infiltration and degranulation in oesophageal mucosa from adult patients with eosinophilic oesophagitis: a retrospective and comparative study on pathological biopsy. J Clin Pathol. 2006;59:1175-1180.

23. Mulder DJ, Pacheco I, Hurlbut DJ, et al. FGF9-induced proliferative response to eosinophilic inflammation in oesophagitis. Gut. 2009;58:166-173.

24. Aceves SS, Newbury RO, Dohil R, Bastian JF, Broide DH. Esophageal remodeling in pediatric eosinophilic esophagitis. J Allergy Clin Immunol. 2007;119:206-212. 
25. Kagalwalla AF, Akhtar N, Woodruff SA, et al. Eosinophilic esophagitis: epithelial mesenchymal transition contributes to esophageal remodeling and reverses with treatment. J Allergy Clin Immunol. 2012;129:1387-1396 e7.

26. Lucendo AJ, Arias A, De Rezende LC, et al. Subepithelial collagen deposition, profibrogenic cytokine gene expression, and changes after prolonged fluticasone propionate treatment in adult eosinophilic esophagitis: a prospective study. J Allergy Clin Immunol. 2011;128:1037-1046.

27. Cheng E, Souza RF, Spechler SJ. Tissue remodeling in eosinophilic esophagitis. Am J Physiol Gastrointest Liver Physiol. 2012;303:G1175-G1187.

28. Aceves SS, Chen D, Newbury RO, et al. Mast cells infiltrate the esophageal smooth muscle in patients with eosinophilic esophagitis, express TGF-beta1, and increase esophageal smooth muscle contraction. J Allergy Clin Immunol. 2010;126:1198-1204 e4.

29. Mishra A, Wang M, Pemmaraju VR, et al. Esophageal remodeling develops as a consequence of tissue specific IL-5-induced eosinophilia. Gastroenterology. 2008;134:204-214.

30. Mavi P, Rajavelu P, Rayapudi M, Paul RJ, Mishra A. Esophageal functional impairments in experimental eosinophilic esophagitis. Am J Physiol Gastrointest Liver Physiol. 2012;302:G1347G1355.

31. Straumann A, Bauer M, Fischer B, Blaser K, Simon HU. Idiopathic eosinophilic esophagitis is associated with a $\mathrm{T}(\mathrm{H}) 2$-type allergic inflammatory response. J Allergy Clin Immunol. 2001; 108:954-961.

32. Straumann A, Kristl J, Conus S, et al. Cytokine expression in healthy and inflamed mucosa: probing the role of eosinophils in the digestive tract. Inflamm Bowel Dis. 2005;11:720-726.

33. Gupta SK, Fitzgerald JF, Kondratyuk T, HogenEsch H. Cytokine expression in normal and inflamed esophageal mucosa: a study into the pathogenesis of allergic eosinophilic esophagitis. $J \mathrm{Pe}$ diatr Gastroenterol Nutr. 2006;42:22-26.

34. Konikoff MR, Blanchard C, Kirby C, et al. Potential of blood eosinophils, eosinophil-derived neurotoxin, and eotaxin-3 as biomarkers of eosinophilic esophagitis. Clin Gastroenterol Hepatol. 2006;4:1328-1336.

35. Straumann A, Aceves SS, Blanchard C, et al. Pediatric and adult eosinophilic esophagitis: similarities and differences. Allergy. 2012;67:477-490.

36. Mishra A, Schlotman J, Wang M, Rothenberg ME. Critical role for adaptive $\mathrm{T}$ cell immunity in experimental eosinophilic esophagitis in mice. J Leukoc Biol. 2007;81:916-924.

37. Vicario M, Blanchard C, Stringer KF, et al. Local B cells and IgE production in the esophageal mucosa in eosinophilic esophagitis. Gut. 2010;59:12-20.

38. Rothenberg ME. Biology and treatment of eosinophilic esophagitis. Gastroenterology. 2009;137:1238-1249.

39. Mishra A, Rothenberg ME. Intratracheal IL-13 induces eosinophilic esophagitis by an IL-5, eotaxin-1, and STAT6-dependent mechanism. Gastroenterology. 2003;125:1419-1427.
40. Ziegler SF. Thymic stromal lymphopoietin and allergic disease. $J$ Allergy Clin Immunol. 2012;130:845-852.

41. Kirsch R, Bokhary R, Marcon MA, Cutz E. Activated mucosal mast cells differentiate eosinophilic (allergic) esophagitis from gastroesophageal reflux disease. J Pediatr Gastroenterol Nutr. 2007;44:20-26.

42. Lucendo AJ, Navarro M, Comas $\mathrm{C}$, et al. Immunophenotypic characterization and quantification of the epithelial inflammatory infiltrate in eosinophilic esophagitis through stereology: an analysis of the cellular mechanisms of the disease and the immunologic capacity of the esophagus. Am J Surg Pathol. 2007;31:598-606.

43. Mueller S, Neureiter D, Aigner T, Stolte M. Comparison of histological parameters for the diagnosis of eosinophilic oesophagitis versus gastro-oesophageal reflux disease on oesophageal biopsy material. Histopathology. 2008;53:676-684.

44. Dellon ES, Chen X, Miller CR, et al. Tryptase staining of mast cells may differentiate eosinophilic esophagitis from gastroesophageal reflux disease. Am J Gastroenterol. 2011;106:264-271.

45. Abonia JP, Blanchard C, Butz BB, et al. Involvement of mast cells in eosinophilic esophagitis. J Allergy Clin Immunol. 2010; 126:140-149.

46. Abonia JP, Franciosi JP, Rothenberg ME. TGF-beta1: mediator of a feedback loop in eosinophilic esophagitis-or should we really say mastocytic esophagitis? J Allergy Clin Immunol. 2010;126:1205-1207.

47. Liacouras CA, Spergel JM, Ruchelli E, et al. Eosinophilic esophagitis: a 10-year experience in 381 children. Clin Gastroenterol Hepatol. 2005;3:1198-1206.

48. Straumann A, Hoesli S, Bussmann C, et al. Anti-eosinophil activity and clinical efficacy of the CRTH2 antagonist OC000459 in eosinophilic esophagitis. Allergy. 2013;68:375-385.

49. Muir AB, Lim DM, Benitez AJ, et al. Esophageal epithelial and mesenchymal cross-talk leads to features of epithelial to mesenchymal transition in vitro. Exp Cell Res. 2012;319:850-859.

50. Blanchard C, Mingler MK, McBride M, et al. Periostin facilitates eosinophil tissue infiltration in allergic lung and esophageal responses. Mucosal Immunol. 2008;1:289-296.

51. Orlando RC. The integrity of the esophageal mucosa. Balance between offensive and defensive mechanisms. Best Pract Res Clin Gastroenterol. 2010;24:873-882.

52. Blanchard C, Stucke EM, Burwinkel K, et al. Coordinate interaction between IL-13 and epithelial differentiation cluster genes in eosinophilic esophagitis. J Immunol. 2010;184:4033-4041.

53. Le-Carlson M, Seki S, Abarbanel D, et al. Markers of antigen presentation and activation on eosinophils and $\mathrm{T}$ cells in the esophageal tissue of patients with eosinophilic esophagitis. $J$ Pediatr Gastroenterol Nutr. 2013;56:257-262.

54. Mulder DJ, Pooni A, Mak N, et al. Antigen presentation and MHC class II expression by human esophageal epithelial cells: role in eosinophilic esophagitis. Am J Pathol. 2011;178:744-753. 